\title{
Theoretical Explanation of Enterprise Diversification
}

\author{
Tao Wang', Chengqiang $\mathrm{Li}^{2}$ \\ ${ }^{1}$ Wuhan Textile University, Wuhan, Hubei, 430200 \\ ${ }^{2}$ China Shipbuilding Industry Corporation, Beijing, China, 10085 \\ Email:foxmoney@163.com
}

Keywords: Enterprise diversification, Strategic management, Theoretic interpretation

\begin{abstract}
In strategic management research, enterprise diversification has become a major study content. And in the enterprise management practice, diversified behavior has become a common practice. It shows that the diversity has an important position in enterprise strategic management. Based on the survey of the domestic and international enterprise diversification of practical experience and literature, from market forces theory, resource theory and agency theory of enterprises, diversified behavior is analyzed in detail. This has a vital significance to enhance China 's enterprises diversification theory accomplishment and practice scientificity.
\end{abstract}

\section{Introduction}

In the strategic management of enterprises, the choice of diversification strategy has become a common enterprise behavior of large international enterprises. However, the practice of diversification in many international and domestic enterprises shows that, in the enterprise that implements the diversification strategy, the successful person also has the loser, not all chooses the diversification enterprise to achieve the ideal effect. Why does the implementation of the diversification strategy result in different results? Different economics have the related study from the different perspectives of management (Asoff, 19571958) [1, 2, 3], business history (Chandler, 1962; Didrichsen, 1972) [9, 15], finance (Reid, 1968), law (Davidson, 198119851986) and marketing (Levitt, 1975; Capon, Hulbert, 1988). In this paper, the author tries to provide a theoretical explanation to the reality of China from the perspective of economics and the Western perspective.

\section{The Fact Description}

In most of the models that economics provides to beginners, enterprises are mostly producers of homogeneity products. This basic hypothesis has an important impact on the way we think about economic behavior. All enterprises in an industry do not seem to have any difference from each other. Managers at the business level rather than the corporate level often seldom consider the company's participation in other markets when making company decisions. If this effect is allowed to continue to play a role, it will mislead the company's development decisions.

However, the fact that a large number of domestic and foreign enterprises diversify is the basis for us to eliminate this concern. The history of the development of enterprises in various countries shows that the diversification of enterprises has become a firm trend.

Table 1 lists the number of business operated by the top 500 American listed companies between 1985 and 1992, and the proportion of various types of companies. Not only in the United States diversification plays an important role in the economy, and the historical trend shows that Canada (Caves, 1980), Japan (Goto, 1981), the UK (Goudie and Meeks, 1982; Utton, 1977) and other developed economies, the trend of diversification is also evident in the last century in 90s $[7,8,16$, 17]. In China, the trend of diversification in the past more than 20 years has been obvious in most of the listed companies (Pan Ruijiao, 2006). Although some failed, but some were successful. 
Table 1. Diversification in the top 500 of the US listed companies.

\begin{tabular}{lccc}
\hline Average value & 1985 & 1989 & 1992 \\
& 10.65 & 10.85 & 10.90 \\
& & 1989 & 1992 \\
\hline Industry code number & 1985 & & \\
& & $12.4 \%$ & $12.4 \%$ \\
1 & $11.8 \%$ & $18.4 \%$ & $18.4 \%$ \\
2 & $18.8 \%$ & $22.6 \%$ & $21.8 \%$ \\
$\leq 3$ & $23.2 \%$ & $68.6 \%$ & $69.6 \%$ \\
$>5$ & $67.6 \%$ & $43.6 \%$ & $43.8 \%$ \\
$>10$ & $42.0 \%$ & $14.0 \%$ & $14.0 \%$ \\
$>30$ & $13.8 \%$ & $0.8 \%$ & $0.8 \%$ \\
\hline
\end{tabular}

Every company has their own purposes in choosing diversification strategy. The key is whether these goals can be realized through diversification. The key is whether the basis for making diversification strategy decisions is reasonable. There are many views on why companies choose to diversify. This paper mainly uses three basic theories to explain corporate diversification: market power theory, principal-generation theory and resource theory.

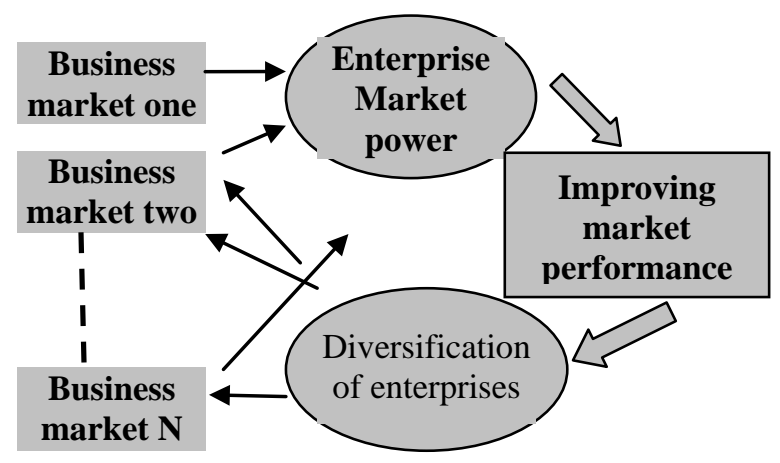

Figure 1. The market power and diversification of enterprises.

\section{The Theory of Market Forces}

Generally speaking, economists' interest in diversification comes from the potential anti competitive effect of diversification. This is similar to the truth that the Chinese proverb "can't put eggs in one basket". This view is first proposed by Corwin Edwards (1955). He believes that the size of a large group is the source of its market power, and diversification is one of the effective means to expand the size of the company. He explained:

Enterprises may have power in specific markets, which not only rely on the position of enterprises in the market organization, but also rely on the scope and characteristics of enterprise activities. It is possible to exploit, extend, or protect the power of an enterprise by diversifying strategies rather than relying on those traditionally linked to monopolies $[4,5]$.

On this basis, economists who follow Edwards have proposed three ways for large group companies to gain power. Cross subsidies, namely the enterprise from a market (sometimes called the "deep pocket") to get profits to support another predatory pricing behavior in the market; mutual restraint, namely common living in market competitors to realize mutual dependence between them so they cannot compete (Bernheim and Whinston, 1990); each purchase, namely large diversified 
enterprise to buy each relationship can prevent small competitors to enter the market [6].

In addition, Gribbin (1976) further points out that the power of large group companies is a function of the market power of the company in each single market [18]. That is to say, in general, a company that does not have an important position in a number of single markets will not have the market power of large group companies. The conclusion is a useful supplement to the above views, together with the theory of market power [14].

To investigate the above research conclusions, we find that there is a logical relationship between market power and enterprise diversification.

The market power of an enterprise is derived from the important position of an enterprise in every business market. Once a company loses its status in a single business market, its total market power will no longer exist. There are several meanings. Enterprises need to manage several businesses at the same time. They play an important role in every business market. This important position can improve the market performance of enterprises, that is, there is a positive correlation between market position and business performance. In the current market environment in China, there are no obstacles to the system in the above three situations. And the way to obtain every business market power is to implement diversification strategy and to go deep into several industries at the same time, that is to say, enterprises diversify.

\section{Agent Theory}

In the US in 1980s, a large number of diversified businesses began to appear sharp changes in business organization, and there was a heated discussion about the suitable scope of diversification. In this process, many financial economists begin to analyze this problem from the perspective of agency theory.

As early as 1932, Berle and Means warned the enterprise that the separation of business owners (principals) and operators (agents) would cause new problems [5]. As Morck, Shleifer and Vishny (1988, p.293) explained: "when managers have little power in the company, and the shareholders are too scattered and maximize the value of the company can't be forced, the assets of the company may make managers benefit rather than by way of a department of shareholders." Mueller (1969), Jensen (1986), Shleifer and Vishny (1989) point out that managers who lack proprietary rights will sacrifice their owners' interests to increase their interests and pursue the strategy of value loss. And annexation - a kind of diversification - is the right tool to do it.

The view that diversification is associated with the growth of the company is a life cycle theory. The view is that the new industry in the development period has a lot of profit opportunities. These opportunities are not easy for enterprises who are already in an industry. Therefore, managers of these enterprises begin to shift the direction of cash flow from early innovation efforts to pursuit of increasing profit opportunities (Mueller, 1972, p.124). Jensen (1986, P.328) describes the cash as "free cash flow", which is the "free cash flow" theory [20]. He wrote:

Merger is a way for managers to spend cash rather than pay to shareholders. Therefore, the theory of free cash flow means that business managers who have the ability to borrow and a large number of free cash flows are more likely to engage in mergers with low returns or even value damages. Multiple procedures generally conform to this category, and the theory predicts that they will produce a lower total income.

The researchers have provided three reasons for the excessive expansion of corporate managers with lack of ownership. First, managers who dominate the business can enjoy the pleasure of building the business kingdom by expanding the size of the company. Second, managers will diversify in a way that increases the company's own specific skills in the manager's own needs. Shleifer and Vishny (1989, p.137) call this behavior management defense, and think that in pursuit of such interest, "managers often invest more than the maximum value of corporate value". Third, generally speaking, business owners can effectively diversify their portfolios, but managers can't diversify their employment risk so efficiently. Therefore, managers may use diversification expansion as a way to reduce company's total risk, which can improve their personal status, but not conducive to company shareholders. According to the research of Amihud and Lev (1981, p.606), 
such a merger can be seen as a form of management subsidy to reduce risks related to managers' human capital. Therefore, the result can be considered as a kind of agency cost."

This theory is applicable to all enterprises which are separated from owners and operators. This is the problem of a typical separation between the owner and the operator, which derives from the reality that the owner is not consistent with the manager's goal. Since the beginning of the reform of modern enterprise system in 90s of last century, Chinese enterprises have entered a period of rapid expansion. The managers who expect higher profits begin to think about using their unique skills to seek a more stable position in the enterprise. Therefore, most of the diversified joint-stock enterprises in this period are diversified behavior dominated by managers. The starting point of this diversification behavior is different from the market power theory. The market power theory emphasizes that the company may benefit from its competitors and consumers, while the agency theory emphasizes that corporate managers may benefit from the interests of shareholders. Therefore, this diversification often shows a negative correlation between diversification and corporate performance.

\section{Resource Theory}

In addition to the theory of market power and agency theory, it can explain reasonably the diversification behavior of enterprises. Some scholars explain the diversification from the perspective of resource utilization, which we call resource theory.

The resource theory, based on the research of Edith Penrose, published a monograph on the theory of corporate growth in 1959. The monograph is different from the traditional economic theory in two important aspects: first, it focuses on the growth of the production of heterogeneous products; second, it is a growth theory rather than an equilibrium theory [12]. These two aspects are necessary to understand the diversification of the company. The basic point of view of the theory of resource is that the company will seek diversification according to the surplus productive capacity of its own productive elements (resources). These resources include the factors that the company buys on the market, the service that the company uses to create, the company's long time accumulation of special knowledge [13]. Penrose believes that the same resources can have different effects in different circumstances; in the production and operation process of the common will create new production services, so long as the expansion of enterprises to provide more efficient use of the resources of the method has been used, a company will have the motivation of diversification.

Further, Teece $(1980,1982)$ points out that Penrose's scope economy has no direct effect on company's width, unless their external transfer is vulnerable to market failure. That is, if the resources that a company is not used can be sold efficiently in the market, the motivation of diversification will disappear. However, in practice, there is a market failure in the sale of many assets. The transfer of physical assets is relatively easy, and market failure often exists when the company's own services and knowledge are transferred. Because many of the companies' skills and knowledge are hidden in the company's practices (Nelson and Winter, 1982). The transfer of these system resources requires the simultaneous transfer of organizational knowledge and personal knowledge (Teece, 1982). The literature on business strategy will argue that making resources difficult to transfer through the company boundaries will also make competitors difficult to imitate, thus becoming a potential source of competitive advantage in their market (for example, Lippman and Rumelt, 1982). When resources do not follow the law of conservation, the value of companies from these resources will increase (Teece, 1980, p.226). For example, when brand names are used in several non-competitive products, they do not cause substantial damage to brand value (Montgomery and Wernerfelt, 1992).

The resource theory holds that the company's profit level and the degree of diversification are the function of the stock of the company. Montgomery and Wernerfelt (1988) point out that the company's resources are different in their specificity. They believe that more professional resources, such as biotechnology in terms of productive skills, are only applied to a few industries effectively, but their marginal benefits will be generated because of their professionalism. On the contrary, less 
professional factors, such as standard milling machines, will further transfer and provide a basis for extensive diversification, but they can only provide lower benefits because of their wide application. This has an important impact on the prediction of the resource theory. Because the companies are different, they will have different levels of diversification. For a company with less professional resources, it will achieve maximum profit at a relatively high level of diversification, and a company with more specialized resources will get absolute high returns because of less diversification [10].

For companies seeking profit maximization, it is universally applicable to make use of all the resources efficiently and reasonably. The full use of the resources in possession is essentially a management problem. Since 90s, the concept of enterprise management in China has changed fundamentally, that is to be efficient to management. Based on the production characteristics of each industry, the production of resources or have the characteristics of economies of scale, or with special characteristics is very strong, or have very high exit costs, therefore, based on the original industrial development is difficult to make the best use of. This has prompted the company to move its goals to other industries, and the motivation to transfer the remaining resources to other industries [11]. The macro-economic policy of China and the prosperous environment of economic development provide favorable conditions for the diversification of the company. So far, enterprises of different ownership, scale of production and different industries are seeking opportunities of diversification. They choose different strategies based on their resource specificity.

\section{Conclusions}

The behavior of corporate diversification has attracted too many scholars' attention and Research on this issue. Based on the analysis of many scholars, this paper explains theoretically the diversification behavior from the perspective of economics. On the above three theoretical explanations, it is of positive significance to the explanation of the diversification behavior of Chinese enterprises. However, according to the theory development practice, the prospects for the development of the three theories are not the same.

Although the theory of market power is concerned by many people, its limitations are very obvious. The main manifestations are as follows: first, the positive relationship between market power and enterprise performance is difficult to prove. Many empirical studies at home and abroad aimed at finding the relationship between corporate performance and the market power of the company have not reached an ideal conclusion. Two, the empirical research on the relationship between them has put forward fine requirements for data and research methods. For current technology and conditions, it is hard to meet this requirement. The three is that the anti-monopoly law issued in 2008 in China is a realistic containment of the monopoly market forces of the enterprise.

In comparison, the two theoretical explanations of agency theory and resource theory may be more promising. The agency theory can reveal the diversity of the company's transcendental efficiency, which is caused by the separation of ownership and management. The explanation of agency theory can provide a scientific basis for enterprise owners to examine the diversification strategy made by the operators. Resource theory is a thorough analysis of the productive surplus resources, so resource theory can help to reveal the right direction of diversification expansion, and the choice of multiple directions is an important part of diversification research. Agency theory and resource theory share the same problem. These two theories do not define the efficiency of corporate diversification, and lack effective ways to provide diversified efficiency levels.

\section{References}

[1] Ansoff, H. I. 'Strategies for diversification', Harvard Business Review, 35(5), 1957, pp. 113-124.

[2] Ansoff, H. I. 'A model for diversification', Management Science, 4, 1958, pp. 392-414.

[3] Ansoff, H. I. Corporate Strategy. McGraw-Hill, New York, 1965. 
[4] Baker, George P., "Beatrice: A Study in the Creation and Destruction of Value," Journal of Finance, July 1992, 47, 1081-119.

[5] Berle, Adolf A., and Gardiner C. Means. The Modern Corporation and Private Property. New York: Macmillan, 1932.

[6] Bernheim, B. Douglas, and Michael D. Whinston, "Multimarket Contact and Collu- sive Behavior," RAND Journal of Economics, Spring 1990, 21, 1-26.

[7] Caves, Richard E., et al., Competition in the Open Economy: A Model Applied to Canada. Cambridge: Harvard University Press, 1980.

[8] Caves, Richard E., "Diversification and Seller Concentration: Evidence from Changes, 1963-72," Review of Economics and Statistics, May 1981, 63, 289-93.

[9] Chandler, A. D. Strategy and Structure: Chapters in the History of the American Industrial Enterprise. MIT Press, Cambridge, MA, 1962.

[10] Collis, David J., "The Walt Disney Com- pany: Corporate Strategy." Boston: Harvard Business School Publishing, 1988.

[11] Collis, David J., and Tomo Noda, "Sharp Corporation: Corporate Strategy." Boston: Harvard Business School Publishing, 1993.

[12] Davidson, K. M. 'Looking at the strategic impact of mergers', Journal of Business Strategy, 2(1), 1981, pp. 13-22.

[13] Davidson, K. M. Megamergers: Corporate America's Billion-Dollar Takeovers. Ballinger, Cambridge, MA, 1985.

[14] Davidson, K. M. 'Megamergers: a scorecard of winners and losers', Wall Street Journal, 20 January 1986, p. 14. Davidson, K. M. 'Do megamergers make sense?', Journal of Business Strategy, 7(3), 1987, pp. 40-48.

[15] Didrichsen, J. 'The development of diversified and conglomerate firms in the United States, 1920-1970', Business History Review, 46(2), 1972, pp. 202-219.

[16] Goto, Akria, "Statistical Evidence on the Diversification of Japanese Large Firms," Journal of Industrial Economics, March 1981, 29, 271-78.

[17] Goudie, A. W., and G. Meeks, "Diversifica- tion by Merger," Economica, November 1982, 49, 447-59.

[18] Gribbin, J. D., "The Conglomerate Merger," Applied Economics, March 1976, 8, 19-35.

[19] Hill, Charles W. L., "Diversified Growth and Competition: The Experience of Twelve Large UK Firms," Applied Economics, October 1985, 17, 827-47.

[20] Jensen, Michael C., "Agency Costs of Free Cash Flow, Corporate Finance, and Take- overs," American Economic Review, May 1986, 76, 323-29. 